\title{
TERMOKİMYASAL ÖN İŞLEM İLE ATIK AKTİF ÇAMURUN PARÇALANMASI
}

Öz: Atık aktif çamurun çürütülmesinde hız sınırlayan aşama, hidroliz aşamasıdır. Biyokimyasal bir süreç olan hidroliz aşamasını kısaltmak ve çürütücü kapasitesini arttırabilmek için, ısıl işlem ve kimyasal çamur parçalama metotları kullanılabilmektedir. Bu çalışmada, atık aktif çamurun 1 sıl işlem, potasyum permanganat ile kimyasal oksidasyon ve bu metodun eş zamanlı kombinasyonu olan ve literatürde rastlanmayan termokimyasal metot ile parçalanması araştırılmıştır. Proses optimizasyonları çözünmüş fazdaki kimyasal oksidasyon ihtiyacı, karbonhidrat ve protein konsantrasyonlarındaki artışa bağlı olarak yapılmıştır. $\mathrm{Bu}$ parametrelere bağlı olarak belirlenen optimum şartların anaerobik çamur çürütmeye etkileri ise biyokimyasal metan üretim testi ile incelenmiştir. Ayrıca, çamurun su verme özelliklerindeki değişim, bulanıklık ve kapiler emme süresi parametreleri ile araştırılmıştır. Sonuç olarak, 1sıl işlem için optimum sıcaklık $100{ }^{\circ} \mathrm{C}$ ve $\mathrm{KMnO}_{4}$ ile kimyasal oksidasyon için optimum konsantrasyon $1000 \mathrm{mg} \mathrm{l}^{-1}$ belirlenmiş iken; termokimyasal ön arıtma metodu için optimum şartlar, $250 \mathrm{mg} \mathrm{l}^{-1}$ lik potasyum permanganat konsantrasyonu ve $100{ }^{\circ} \mathrm{C}$ sicaklık olarak belirlenmiştir. Bu şartlarda termokimyasal ön arıtmanın, anaerobik çürütmede ham çamura kıyasla, biyogaz üretimini \% 38 ve metan gazı üretimini ise \% 34 oranında arttırdığı belirlenmiştir. Sonuç olarak termokimyasal ön arıtmanın, kimyasal oksidason metoduna kıyasla, daha yüksek verimle çamur parçaladığı ve daha düşük kimyasal dozlarında bile çamur çürütmeyi geliştirdiği belirlenmiştir.

Anahtar Kelimeler: Atık aktif çamur, Çamur parçalama, Isıl işlem, Kimyasal oksidasyon, Potasyum permanganat.

\section{Disintegration of Waste Activated Sludge via Thermo-Chemical Pre-Treatment}

\begin{abstract}
The rate limiting step in the digestion of the waste active sludge is hydrolysis the stage. Thermal pre-treatment and chemical sludge disintegration methods can be used to shorten the biochemical hydrolysis process and increase the digester capacity. In this study, the disintegration of waste activated sludge via thermal pre-treatment, chemical oxidation using potassium permanganate and thermo-chemical disintegration method (which is a simultaneous combination of thermal pre-treatment and chemical oxidation) was investigated. Optimizations of these methods were carried out depend on the increases in chemical oxidation demand, carbohydrate and protein concentrations in the dissolved phase. In addition, biochemical methan production tests were performed under the optimized conditions in order to determine the influences of these methods on biogas production. On the other hand, the change in dewaterability of waste sludge was investigated by parameters of turbidity and capillary suction time (CST). As a result, the optimum temperature for thermal pre-treatment is $100{ }^{\circ} \mathrm{C}$ and the optimum concentration for chemical oxidation with $\mathrm{KMnO}_{4}$ is $1000 \mathrm{mg} \mathrm{l}^{-1}$; the optimum conditions for the thermochemical pre-treatment method were determined to be a concentration of $250 \mathrm{mg} \mathrm{l}^{-1}$ potassium permanganate and a temperature of $100{ }^{\circ} \mathrm{C}$. In these conditions, the thermo-chemical pre-treatment was found to increase biogas production by $38 \%$ and methane production by $34 \%$ compared to anaerobic digestion of the raw (unpre-treated) sludge. As a result, thermo-chemical pre-treatment has been found to
\end{abstract}

\footnotetext{
*Nevşehir Hacı Bektaş Veli Üniversitesi, Mühendislik Mimarlık Fakültesi, Çevre Mühendisliği Bölümü, 50300, Merkez, Nevşehir

İletişim Yazarı: Serkan Şahinkaya (serkansahinkaya@gmail.com)
} 
solubilize the sludge more efficiently and to improve the anaerobic digestion of sludge even at lower chemical doses compared to chemical oxidation method.

Keywords: Chemical oxidation, Potassium permanganate, Sludge disintegration, Thermal pre-treatment, Waste activated sludge.

\section{GİRIŞ}

Evsel nitelikli atıksuların arıtılmasında biyolojik bir atıksu arıtma süreci olan aktif çamur prosesi yaygın olarak kullanılmaktadır. Aktif çamur prosesi ile atıksu içerisindeki organik maddeler, karışık bir biyokütle tarafından besin kaynağı olarak kullanılarak giderilmektedir. Ancak biyokütlenin bu faaliyeti sırasında kaçınılmaz olarak fazla biyokütle üretilmektedir. Sistemden uzaklaştırılması gereken bu fazla biyokütleye, "atık aktif çamur (AAÇ)" denilmektedir. Atık biyolojik arıtma çamurları, patojen mikroorganizmalar ile kolayca bozunabilen ve kokuşabilen organik maddeleri de içerdiği için, uzaklaştırılmadan önce arıtılmaları gerekmektedir. Çamurun kompleks yapılı organik madde içeriği çok yüksek olduğu için, çamur çürütücülerdeki biyokimyasal hidroliz, hız sınırlayan aşamadır (Carrère ve diğ., 2010). Bu nedenle atık aktif çamuru çürütmek için büyük çürütücülere ihtiyaç duyulmaktadır. $\mathrm{Bu}$ durum ilk yatırım ve işletme maliyetlerinin artmasına neden olmaktadır. Ekonomik açıdan çamur bertarafı, arıtma tesisinin toplam ilk yatırım masraflarının \% 30 - 40'ını, işletme masrafının ise yaklaşık \% 50'sini oluşturmaktadır (Vlyssides ve Karlis, 2004). Sonuç olarak hem çevresel hem de ekonomik açıdan arıtma çamurlarının bertaraf edilmesi, tesisler için önemli bir sorundur.

Atık aktif çamurun arıtılması amacıyla, küçük ölçekli tesislerde aerobik çürütücüler, büyük ölçekli tesislerde ise anaerobik çürütücüler yaygın olarak kullanılmaktadır. Son yıllarda araştırmacılar bu çürütücülerin ilk yatırım ve işletme maliyetlerinin azaltılabilmesi için, çamur ön arıtma metotları üzerinde durmaktadırlar. Bu çamur ön arıtma metotlarından bazıları, alkali arıtma, 1sıl işlem, ultrasonik çamur parçalama, mikrodalga radyasyonu ile çamur parçalama, kimyasal oksidasyon metotları ile atık çamurun parçalanmasıdır.

Isıl işlem, AAÇ’nin parçalanması için detaylı olarak araştırılmış bir ön arıtma metodudur. Isıl işlem, düşük ve yüksek sıcaklık uygulamaları olarak ikiye ayrılmaktadır. Uygulanan sıcaklık arttıkça, çamur parçalama verimi artmaktadır. Ancak $180{ }^{\circ} \mathrm{C}$ 'nin üzerindeki sıcaklıklarda, Maillard reaksiyonu sonucunda toksik ve biyolojik parçalanabilirliği az olan reaksiyon ürünleri oluşmaktadır (Wilson ve Novak, 2009). Bu da artan çamur çözünürlüğ̈̈ne rağmen, çamurun çürütülebilirliği engellemektedir. Bu nedenle yapılan araştırmalarda $100{ }^{\circ} \mathrm{C}$ civarındaki düşük sıcaklık uygulamaları öne çıkmaktadır (Ferrer ve diğ., 2008). Düşük sıcaklık uygulamasının bir başka önemli avantajı ise, daha az enerji sarf edilmesidir. Bu nedenlerle, bu çalışmada da düşük sıcaklık uygulaması potasyum permanganat kullanılarak çamurun parçalanması için hibrit bir metodun oluşturulmasında değerlendirilmiştir.

Kimyasal madde kullanarak çamur parçalama, son yıllarda denenmeye başlamıştır. $\mathrm{Bu}$ uygulamalardan bazıları, ozon, Fenton reaktifi, hidrojen peroksit ve potasyum permanganattır. Bunlardan ozon uygulaması, ozonun üretildiği yer ve anda kullanım gerektirmesi, tesis için gerekli kapasitede ozon jeneratörünün ilk yatırım maliyetinin çok yüksek olması, ozon üretiminin elektrik sarfiyatına bağlı olması ve bunun da işletme maliyetini arttırması ve kalifiye eleman gerektirmesi gibi dezavantajları vardır. İleri oksidasyon metodu olan Fenton reaktifi uygulamasında ise, $\mathrm{pH}$ 'ın asidik şartlara ayarlanması, demir ve hidrojen peroksit dozlamaları ile reaksiyon aşaması ve sonra pH'ın nötral değerlere ayarlanması olmak üzere 4 farklı aşaması ile birkaç bölmeden oluşan bir reaktör gerektirmektedir. Ayrıca kullanılan tüm kimyasallar için depo ve dozlama aparatları ile kalifiye personel bulunmalıdır. Öte yandan, uygulanan demir dozu, çamurun kullanımını (bertaraf aşamasında) sınırlayabilecektir. Bu uygulamaların aksine, potasyum permanganat depolanabilir, $\mathrm{pH}$ ayarı gerektirmeyen, basit ve klasik kimyasal oksidasyona dayalı bir metodudur (Wu ve diğ., 2014). 
Literatürde, kuvvetli bir kimyasal oksidant olan potasyum permanganatın çamur parçalamada kullanıldığı sınırlı sayıda çalışma bulunmaktadır. Bu çalışmaların birinde, $\mathrm{Wu}$ ve diğ. (2014), potasyum permanganatın çamuru parçalama mekanizmasının, hücreleri bir arada tutan ve çoğunlukla protein ve karbonhidrattan oluşan hücrelerarası polimerik maddelerin okside olmasından kaynaklandığını belirlemişlerdir. Ancak Wu ve diğg. (2014) potasyum permanganat ile çamur parçalamanın çamurun fiziksel özellikleri ile biyolojik çürütülebilirliğine etkilerini incelememişlerdir. Bir başka çalışmada ise Zhang ve diğ. (2012) çalışmalarını potasyum permanganat ile ön işlemin sadece çamurun su verme özelliğine etkisi üzerine odaklanarak sınırlamışlardır. Zhang ve diğ. (2012), pH 3'te gerçekleştirilen ön işlemin çamurun su verme özelliğini geliştirdiği ancak $\mathrm{pH} 4-8$ aralığında yapılan potasyum permangat ön işleminin ise çamurun su verme özelliğini kötüleştirdiği belirlenmiştir. Öte yandan, bu çalışmaların dışında potasyum permanganat ile AAÇ’nin parçalandığı bir başka çalışmaya rastlanamamıştır. Literatürde, hem sadece potasyum permanganat ile ön işlemin çamurun fiziksel ve kimyasal özellikleri ile biyolojik çürütülebilirliğine etkisinin araştırıldığı derleyici bir çalışmaya rastlanmamıştır. Ayrıca, ısıl işlemin, potasyum permanganat oksidasyonu ile eş zamanlı kombinasyonundan oluşan termokimyasal ön işlemin de literatürde bir örneği bulunmamaktadır. Bu yönleri, çalışmanın en özgün yanlarını oluşturmaktadır.

Sunulan bu çalışma kapsamında 1 sıl işlem, potasyum permanganat ile kimyasal çamur parçalama ve bu iki metodun eş zamanlı uygulaması olan termokimyasal çamur ön arıtımı metotları ile atık aktif çamurun parçalanmasına ve biyogaz üretimine etkileri araştırılmıştır. Bu üç çamur parçalama metodunun etkinlikleri, çözünmüş fazda kimyasal oksijen ihtiyacı (KOİ), protein ve karbonhidrat konsantrasyonları ile bulanıklık parametreleri ile değerlendirilmiştir. Ön arıtma metotlarının çamurun önemli bir fiziksel özelliği olan su verme özelliğine etkisi ise kapiler emme süresi (KES) parametresi ile ölçülmüştür. Çamur parçalama metotlarının çamurun çürütülmesine etkisi - kimyasal parametrelere ilave olarak - kesikli anaerobik reaktörlerde biyokimyasal metan üretim testi ile araştırılmıştır.

\section{MATERYAL VE METOT}

\subsection{Atık Aktif Çamur}

Deneylerde kullanılan AAÇ, kentsel atıksu arıtma tesisinden sağlanmıştır. AAÇ numuneleri, çökeltme havuzundan havalandırma havuzuna gelen çamur geri devir hattından alınmıştır. Deneylerden önce çamurun TKM içeriği, gravite ile yoğunlaştırarak ve/veya ultra saf su ilave ederek \% 1 katı madde içeriğine ayarlanmıştır. Deneylerde kullanılan ve \% 1 TKM içeriğine sahip AAÇ'nin bazı önemli özellikleri Tablo 1'de sunulmuştur.

AAÇ, çamurun mikrobiyal aktivitesini koruyabilmek için soğutucuda $+4{ }^{\circ} \mathrm{C}$ sicaklıkta ve karanlıkta saklanmıştır. AAÇ, anoksik şartların oluşmasını engellemek için günlük 10 dakika süreyle havalandırılmıştır. AAÇ'nin bozulma ihtimaline karşı deneylerde en fazla 7 gün süreyle kullanılmıştır.

\subsection{Deneysel Çalışma}

Çalışma kapsamında ilk aşamada potasyum permanganat kullanarak kimyasal oksidasyon ile çamurun parçalanması, 1 șil işlem ile mekanik çamur parçalama ve bu iki metodun eş zamanlı kombinasyonu olan termokimyasal çamur parçalama süreçlerinin optimizasyonları gerçekleştirilmiştir. İkinci aşamada ise, optimum şartlarda gerçekleştirilen parçalamanın çürütme verimine etkisi kesikli anaerobik çürütme deneyleriyle araştırılmıştır. Analizlerde kullanılan çözeltiler, ultra saf su kullanarak hazırlanmıştır. Kullanılan kimyasal maddelerin tümü analitik saflığa sahiptir.

Potasyum permanganat ile kimyasal çamur parçalama, jar test düzeneğinde $250 \mathrm{ml}$ hacminde AAÇ kullanılarak oda sıcaklığında gerçekleştirilmiştir. Kimyasal çamur parçalama sürecinin potasyum permanganat ilave edildiği anda başladığ 1 kabul edilmiştir. Potasyum permanganat, atık aktif çamur içerisinde $250,500,1000$ ve $1500 \mathrm{mg} \mathrm{l}^{-1}$ konsantrasyonlarını 
sağlayacak miktarda ilave edilmiştir. Potasyum permanganat ilavesinden sonra atık aktif çamur, sürekli olarak $60 \mathrm{rpm}$ devir hızında karıştırılmıştır. Kimyasal oksidasyon ile çamur parçalama deneyinin süreleri ise $15,30,45$ ve 60 dakika olarak belirlenmiştir. Bu sürelerin sonunda jar testinde karıştırma durdurulmuş ve çamur numuneleri alınarak fiziksel ve kimyasal analizleri gerçekleştirilmiştir.

Isıl işlem ile çamur parçalama deneyleri, $250 \mathrm{ml}$ hacminde AAÇ kullanılarak gerçekleştirilmiştir. Parçalama deneyleri etüv içerisinde, AAÇ, buharlaşmayı önlemek için cam kapaklı bir balon joje içerisinde bekleterek gerçekleştirilmiştir. Termal işlem deneyleri 80, 100 ve $120{ }^{\circ} \mathrm{C}$ sicaklıklarda bir saat süre ile çalkalama yapılmadan yürütülmüş̧ür. 1 saatlik parçalama sürecinin sonunda ise çamur örnekleri etüvden çıkartılarak, sıcaklıkları oda sıcaklığına düşene kadar bekletilmiş ve sonrasında analizler gerçekleştirilmiştir.

Termokimyasal çamur parçalama uygulaması, yukarıda özetlendiği şekilde, hem potasyum permanganat ile kimyasal oksidasyon hem de 1 sıl parçalama metotlarının eş zamanlı kombinasyonu olarak gerçekleştirilmiştir. $\mathrm{Bu}$ deneylerde, $250 \mathrm{ml}$ hacmindeki balon joje içerisindeki çamura $250,500,1000$ ve $1500 \mathrm{mg} \mathrm{l}^{-1}$ konsantrasyonlarını sağlayacak miktarda potasyum permanganat ilave edilmiştir. AAÇ karıştırıldıktan sonra bekletilmeden (optimum sicaklık olarak belirlenen) $100{ }^{\circ} \mathrm{C}$ 'deki etüvde bir saat süreyle cam kapaklı bir balon joje içerisinde tutulmuştur. $\mathrm{Bu}$ bir saatlik sürenin sonunda çamur oda sıcaklığına gelene kadar bekletilerek soğutulmuş ve sonra fiziksel ve kimyasal analizleri gerçekleştirilmiştir. Optimum şartlarda her üç metodun da çamurun biyolojik parçalanabilirliğine ve metan üretimine etkilerini görebilmek için biyokimyasal metan üretim (BMP) testileri yapılmıştır.

Tablo 1. AAÇ’nin karakteristik özellikleri.

\begin{tabular}{|l|c|}
\hline Parametre & Değer \\
\hline $\mathrm{pH}$ & 7,4 \\
\hline Toplam kimyasal oksijen ihtiyacı (tKOİ), $\mathrm{mg} \mathrm{l}^{-1}$ & 9640 \\
\hline Çözünmüş kimyasal oksijen ihtiyacı (çKOİ), mg l-1 & 75 \\
\hline Toplam katı madde (TKM), mg l ${ }^{-1}$ & 10515 \\
\hline Uçucu katı madde (UKM), mg l ${ }^{-1}$ & 7400 \\
\hline Askıda katı madde (AKM), mg l ${ }^{-1}$ & 8180 \\
\hline Uçucu askıda katı madde (UAKM), mg l-1 & 6235 \\
\hline Çözünmüş protein (çProtein), mg l-1 & 30 \\
\hline Çözünmüş karbonhidrat (çKarbonhidrat), mg l'-1 & 30 \\
\hline Bulanıklık, NTU & 15 \\
\hline Kapiler emme süresi (KES), s & 8,5 \\
\hline
\end{tabular}

\subsection{Analizler}

Deneysel çalışma süresince gerçekleştirilen ölçümler, AAÇ ve anaerobik aşı çamurunda da yapılmıştır. Bu ölçümlerden TKM, UKM, AKM, UAKM, \% TKM içeriği, pH, sıcaklık, çKOİ, tKOİ analizleri Standart Metotlara (APHA, 2005) uygun olarak yapılmıştır. Çamurun 
parçalanmasının en genel göstergesi olan parçalama derecesi $\left(\mathrm{PD}_{\mathrm{KOI}}\right)$ ise çözünmüş KOİ parametresindeki artışa bağlı olarak (Eşitlik 1'de gösterildiği gibi) hesaplanmıştır.

AAÇ’nin hücresel bileşeninin büyük çoğunluğunu karbonhidrat ve proteinler oluşturmaktadır. Bu nedenle çamurun parçalanmasından sonra çözünmüş fazdaki protein ve karbonhidrat konsantrasyonlarındeki artış, modifiye Lowry metodu (Lowry ve diğ., 1951) ve fenol-sülfürik asit metodu (Dubois ve diğ., 1959) ile ölçülmüş̧ür.

Çamur floklarını bir arada tutan hücrelerarası bileşenlerin parçalanması, hücresel bileşene varana kadar çamur floklarını dağıtmakta ve böylece bulanıklığın aşırı derece artmasına neden olmaktadır. Bu nedenle bulanıklık parametresi Velp marka türbidimetre ile ölçülmüştür.

Çamurun parçalanması sonucunda hücreler arası ve hücre içi karbonhidrat ve protein gibi bileşenler sıvı faza geçerek, çamurun viskozitesini arttırmaktadır. Bu da çamurun su verme özelliğinin değişmesine neden olmaktadır. Su verme özelliğindeki değişimin belirlenebileceği en basit ve küresel ölçekte tanınan parametre ise kapiler emme süresi (KES)'dir. KES ölçümleri Triton marka KES ölçer ile gerçekleştirilmiştir.

Ön arıtma uygulandıktan sonra, süreç verimini belirlemek için yapılan ölçümler, çKOİ, çözünmüş protein ve çözünmüş karbonhidrattır. Ayrıca, optimum şartlarda uygulanan ön arıtma metotlarının toplam biyogaz ve metan üretimlerine etkilerinin belirlenebilmesi için BMP testleri de yapılmıştır.

$$
P D_{K O \dot{I}}=\frac{c ̧ K O \dot{\mathrm{I}}_{\text {son }}-c ̧ K O \dot{\mathrm{I}}_{\text {başlang } \iota c ̧}}{t K O \dot{\mathrm{I}}-c_{K O} \dot{\mathrm{I}}_{\text {başlangıc }}}
$$

BMP testleri, ön arıtma ile sağlanan çamur parçalamanın anaerobik çamur çürütmede çamur stabilizasyonuna ve metan üretimine etkilerinin belirlenmesi amacı ile yapılmıştır. BMP testleri, bulanıklık, çKOİ, protein ve karbonhidrata bağlı olarak belirlenen optimum şartlarda ön arıtılmış çamur örnekleri için gerçekleştirilmiştir. BMP deneyleri üçer kez tekrarlanmıştır. Anaerobik aşı çamuru, aktif çamur sürecini kullanan bir endüstriyel atıksu arıtma tesisine ait anaerobik bir çamur çürütücüden alınmıştır. BMP testi, Eskicioğlu ve diğerlerinin (2007) çalışmasında uyguladığı prosedüre uygun olarak gerçekleştirilmiştir. BMP testleri aşı çamuru, ham AAÇ ve ön arıtmadan geçmiş AAÇ için toplam hacmi $120 \mathrm{ml}$ olan alüminyum folyoya sarılı şişelerde yapılmıştır. Şişelere $20 \mathrm{ml}$ anaerobik aşı çamuru ve $80 \mathrm{ml}$ atık çamur ilave edilmiştir. Toplam alkalinite, eşit miktarda alkalinite oluşturacak kadar sodyum bikarbonat $\left(\mathrm{NaHCO}_{3}\right)$ ve potasyum bikarbonat $\left(\mathrm{KHCO}_{3}\right)$ ilavesiyle $4000 \mathrm{mg} \mathrm{l}^{-1} \mathrm{CaCO}_{3}$ 'a ayarlanmıştır. Şişeler kauçuk tıpa ve delikli vidalı kapaklar ile kapatılmışlardır. Şişelerde kalan serbest oksijeni süpürmek için ortam 2 dakika boyunca azot $\left(\mathrm{N}_{2}\right)$ gazı ile yıkanmıştır. Bu nedenle, başlangıçtaki gazın tamamının azot $\left(\mathrm{N}_{2}\right)$ olduğu kabul edilmiştir. Kesikli reaktörler, biyogaz üretimi duruncaya kadar $37 \pm 1{ }^{\circ} \mathrm{C}$ 'de inkübatörde tutulmuş ve günde iki kez elle çalkalanmıştır. BMP testi kesikli bir deney olduğu için, reaktörlere besleme veya reaktörlerden numune çekimi yapılmamıştır. Volümetrik metotla ölçülen toplam biyogaz ve metan ölçümleri iki günde bir gerçekleştirilmiştir. Günlük gaz üretimi ihmal edilebilir seviyeye düştükten sonra BMP testleri sonlandırılmış ve reaktörler açılarak tKOİ, TKM, UKM ve KES analizleri yapılmıştır. Anaerobik çamur çürütme verimleri, tKOİ ve UKM parametrelerine dayanarak belirlenmiştir.

\section{SONUÇLAR VE TARTIŞMA}

Deneysel çalışma iki aşamada gerçekleştirilmiştir. İlk aşamada, 1 sıl işlem, potasyum permanganat ile oksidasyon ve termal+potasyum permanganat (termokimyasal ön arıtma) ile çamur parçalamaya tesir eden şartların incelenmesidir. Kimyasal parametrelere göre proses optimizasyonu yapıldıktan sonra, ikinci aşamada optimum şartlardaki her üç metodunda biyogaz ve metan üretimine olan katkısı, BMP testleri ile belirlenmiştir.

\subsection{Potasyum Permanganat ile Kimyasal Çamur Parçalama}

Potasyum permanganat, güçlü bir kimyasal oksitleyicidir. Asidik ve alkali şartlardaki oksidasyon redüksüyon potansiyelleri (E), sırasıyla Eşitlik 2 ve 3'te sunulmuştur (Wu ve diğ., 
2014). Geniş bir pH aralığında oksidasyonu gerçekleştirebilme özelliği sayesinde çamur parçalama amacıyla da kullanılabilmektedir. Bu amaçla kullanıldığında hem çamur floklarını bir arada tutan protein ve karbonhidrat gibi organik maddelerden oluşan hücrelerarası polimerik maddeleri parçalayarak flokları dağıtmakta hem de hücre duvarlarına nüfus ederek hücre içi materyallerin hücre dışına çıkmasını sağlamaktadır (Wu ve diğ., 2014). Böylece oksidasyon mekanizması ile çamurun çözünmüş fazındaki organik madde içeriği önemde derecede arttırılabilmektedir. Aşırı miktarda kullanılması ise sıv1 faza geçen organik maddelerin oksidasyonuna neden olmaktadır. Bu çalışma kapsamında potasyum permanganat dozunun optimizasyonu için gerçekleştirilen deneylerde 250 - $1500 \mathrm{mg} \mathrm{l}^{-1}$ doz aralığ incelenmiştir. Sonuçlar Şekil 1'de sunulmuştur.

$$
\begin{array}{cl}
\mathrm{MnO}_{4}^{-}+8 \mathrm{H}^{+}+5 e \rightarrow \mathrm{Mn}^{2+}+4 \mathrm{H}_{2} \mathrm{O} & \mathrm{E}=1.51 \mathrm{~V} \\
\mathrm{MnO}_{4}^{-}+2 \mathrm{H}_{2} \mathrm{O}+3 e \rightarrow \mathrm{MnO}_{2}+4 \mathrm{OH}^{-} & \mathrm{E}=0.59 \mathrm{~V}
\end{array}
$$
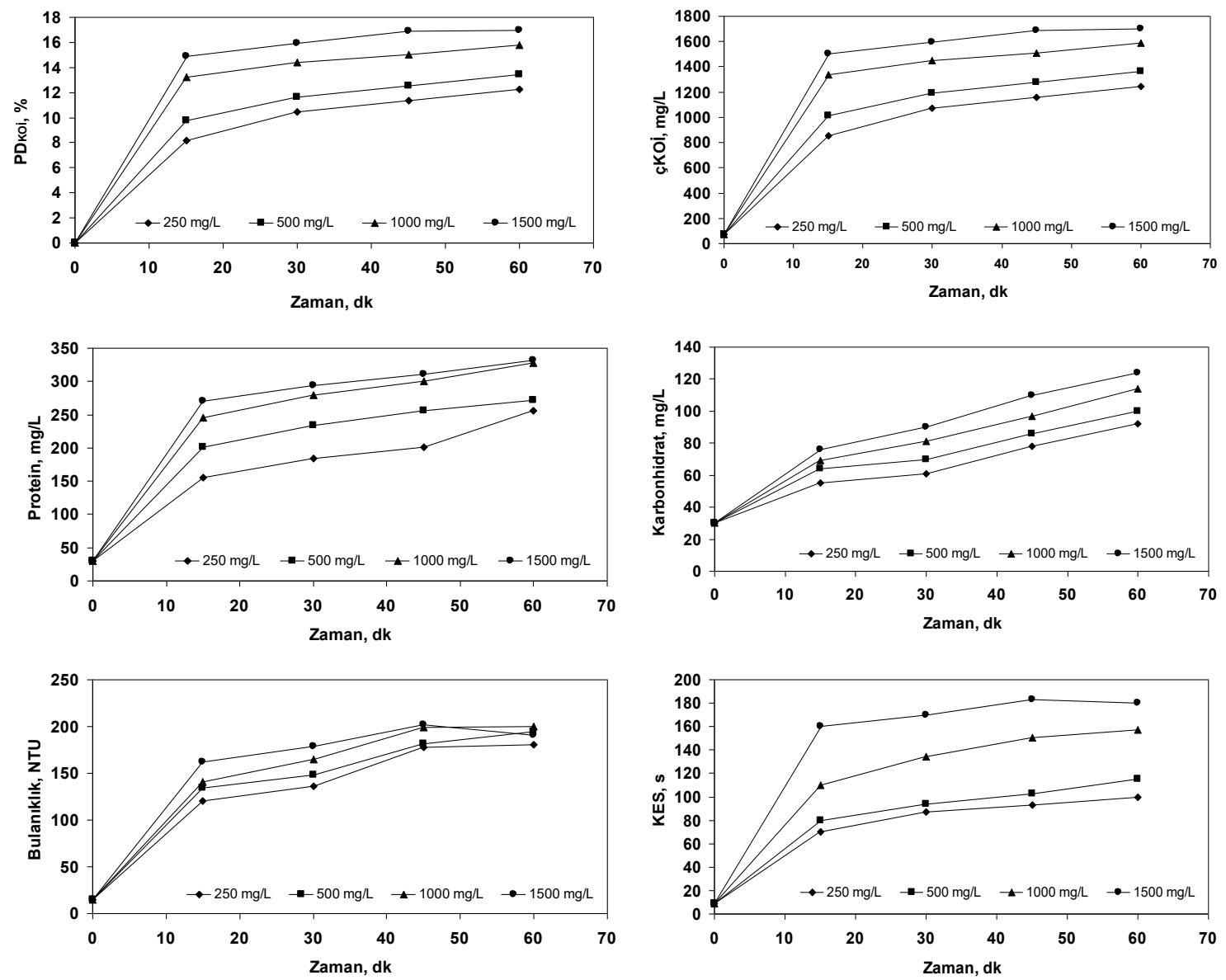

Şekil 1:

Potasyum permanganat ile kimyasal çamur parçalama.

$\mathrm{KMnO}_{4}$ ile çamurun parçalanması özellikle ilk 15 dakikada çok hızlı gerçekleşmiştir. $\mathrm{Bu}$ sonuç, reaksiyonun başında $\mathrm{KMnO}_{4}$ 'ün ortamda bol bulunmasından kaynaklanmış ve ortamdaki varlı̆̆ azaldıkça parçalama hızı da azalmıştır. Kuvvetli bir oksidant olan permanganatın artan dozu ile çamur parçalama verimi artmıştır. Bu sonuca uygun olarak, artan kimyasal dozlaması

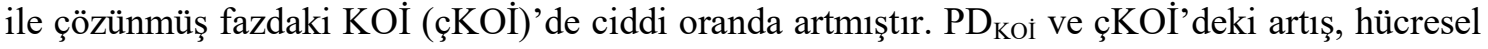
bileşenler olan karbonhidrat ve protein konsantrasyonlarındaki artış ile uyumlu bir sonuçtur. $\mathrm{Bu}$ sonucun bir başka göstergesi de dağılan floklardan dolayı küçülen tanecik boyutu ile artan bulanıklık değeridir. Böylece artan potasyum permanganat dozu, oksidant etkisi ile öncelikle 
AAÇ içerisindeki flokları dağıtıp, dağılan floklarda yer alan mikrobiyal hücrelerin duvarlarını yıkarak ve hücreleri parçalayarak hücresel bileşenleri katı fazdan çözünmüş faza geçirmiştir. Bu sonuçlar Wu ve diğerleri (2014) ile Demir'in (2016) çalışmalarında buldukları sonuçlar ile uyumludur.

Potasyum permanganat ile kimyasal çamur parçalama için proses optimizasyonunda, esas parametre çözünmüş fazdaki KOİ, karbonhidrat ve protein konsantrasyonlarındaki değişimlerin de genel göstergesi olan $\mathrm{PD}_{\text {Коі }}$ parametresidir. Şekil 3'te de gösterildiği gibi, $1000 \mathrm{mg} \mathrm{l}^{-1}$ nihai konsantrasyonuna kadar, çamur parçalama etkisi hızla artarken; $1500 \mathrm{mg} \mathrm{l}^{-1}$ dozunda bu etki (uygulanan dozdaki artışa kıyasla) kayda değer olmamıştır. Çözünmüş fazdaki organik maddelerin konsantrasyonundaki bu sınırlı artış, sıvı fazdaki fazla permanganatın oksitleyici etkisinden kaynaklanmıştır. $\mathrm{Bu}$ nedenle, potasyum permanganat için $1000 \mathrm{mg}^{-1}$ 'lik konsantrasyon, optimum olarak belirlenmiştir.

Potasyum permanganat ile çamur parçalamanın, uygulanan tüm dozlarda su verme özelliği üzerine etkileri de incelenmiştir. Çamurun su verme özelliği kapiler emme süresi (KES) parametresi ile ölçülmüsstür. Şekil 1'de gösterildiği gibi, uygulanan $\mathrm{KMnO}_{4}$ dozu arttıkça çamurun su verme özelliği ciddi derecede azalmıştır. Su verme özelliğindeki bu kötüleşme, çamurun parçalanması ile birlikte sıvı faza geçen protein ve karbonhidrat gibi polimerik maddelerin artan konsantrasyonundan ve küçülen partikül boyutundan kaynaklanmıştır.

\subsection{Isıl İşlem işe Çamurun Parçalanması}

Isıl işlemin deneysel sonuçları Tablo 2'de sunulmuştur. Bu tablodan da anlaşılacağ gibi, artan sıcaklık ile çözünmüş fazdaki organik madde konsantrasyonu sürekli artmış, yani çamur parçalanma verimi sürekli iyileşmiştir. Bunun nedeni, artan sıcaklıkla önce flokları bir arada tutan hücreler arası polimerik maddelerin çözünerek flokların dağılması, sonrasında da hücre duvarlarının yapısının bozularak protein ve karbonhidrat gibi maddelerden oluşan hücre içeriklerinin sıvı faza geçmesidir. Böylece bulanıklık ile çözünmüş fazdaki karbonhidrat, protein ve KOİ'nin artmıştır. Çamur parçalama veriminin temel göstergesi olan $\mathrm{PD}_{\mathrm{KO}}$ değeri, sicaklığın $80{ }^{\circ} \mathrm{C}$ 'den $100{ }^{\circ} \mathrm{C}$ 'ye yükselmesi ile ciddi derecede artarken; sıcaklığın $120^{\circ} \mathrm{C}$ 'ye yükseltilmesi kayda değer bir artışa neden olmamıştır. Şahinkaya ve Sevimli (2013) tarafından düşük sıcaklıklarda gerçekleştirilen çalışmada da, benzer şekilde artan sıcaklıkla çamurun çözünürlüğü artmiştır.

Çamur parçalamanın sonucunda, küçülen tanecik büyüklüğü ve artan polimerik madde konsantrasyonu neticesinde, KES değerleri artmıştır (Tablo 2). Yani çamurun su verme özelliği kötüleşmiştir. Ancak ısıl işlemin şartlandırma özelliğinden dolayı, bu kötüleşme, $\mathrm{KMnO}_{4}$ ile kimyasal oksidasyondaki kadar kötü olmamıştır. Sonuç olarak, çamurun parçalanmasındaki esas gösterge olan $\mathrm{PD}_{\text {Kоі }}$ verilerine bakarak, optimum sıcaklık değerinin $100{ }^{\circ} \mathrm{C}$ olduğu belirlenmiştir.

Tablo 2. Termal işlem ile çamur parçalama deney sonuçları.

\begin{tabular}{|c|c|c|c|c|c|c|}
\hline $\begin{array}{l}\text { Sicaklık } \\
{ }^{\circ} \mathbf{C}\end{array}$ & $\begin{array}{c}\text { Bulanıklık } \\
\text { NTU }\end{array}$ & $\begin{array}{c}\text { Karbonhidrat } \\
\mathrm{mg} \mathrm{l}^{-1}\end{array}$ & $\begin{array}{c}\text { Protein } \\
\mathrm{mg} \mathrm{l}^{-1}\end{array}$ & $\begin{array}{l}\text { çKOİ } \\
\text { mg l}^{-1}\end{array}$ & $\begin{array}{c}\text { PD }_{\text {коі }} \\
\%\end{array}$ & $\begin{array}{c}\text { KES } \\
\text { s }\end{array}$ \\
\hline Ham AAÇ & 15 & 30 & 30 & 75 & - & 8,5 \\
\hline $80^{\circ} \mathrm{C}$ & 76,5 & 42 & 135 & 790 & 7,4 & 30,4 \\
\hline $100^{\circ} \mathrm{C}$ & 128,3 & 61 & 205 & 1215 & 11,9 & 41,7 \\
\hline $120^{\circ} \mathrm{C}$ & 151,7 & 72 & 235 & 1340 & 13,2 & 50,4 \\
\hline
\end{tabular}




\subsection{Termokimyasal Çamur Parçalama}

Termokimyasal çamur parçalama süreci, ısıl işlem ile potasyum permanganat oksidasyonunun eş zamanlı uygulamasıdır. Şekil 2'den de anlaşılacağı gibi, $100{ }^{\circ} \mathrm{C}$ 'lik sabit sicaklıkta, artan potasyum permanganat dozu ile çözünmüş fazdaki KOİ, protein ve karbonhidrat konsantrasyonları sürekli yükselmiş; yani çamur parçalama verimi sürekli iyileşmiştir. Bunun nedeni, öncelikle çamurun maruz kaldığı oksitleyici permanganat dozunun sürekli artması ve $100{ }^{\circ} \mathrm{C}$ sıcaklıkta dağılmış/parçalanmış çamur floklarının daha şiddetli şekilde potasyum permanganata maruz kalmasıdır. Buna uygun olarak, Şekil 2'de gösterildiği gibi, çözünmüş fazdaki artan protein, karbonhidrat ve KOİ konsantrasyonları, çamurun hızla parçalandığını göstermektedir. Buna göre, artan dozlama ile çamur floklarının dağıtılması ile kimyasal çamur parçalama verimi sürekli şekilde arttırılmıştır. Isıl işlem ile potasyum permanganatın eş zamanlı kombinasyonunun, sinerjetik bir etki geliştirdiği ve her iki metodunda münferit verimlerinden fazla bir verimle çamuru parçaladığı belirlenmiştir (Tablo 3). \% 2.2 PDKOİ oranıyla sınırlı da olsa bu sinerjetik etki, $100{ }^{\circ} \mathrm{C}$ sıcaklıkta çamur floklarının ve mikrobiyal hücrelerin, permanganat tarafindan daha kolay parçalanabilmesinden kaynaklanmıştır. Potasyum permanganat dozu arttıkça sinerjetik etki de hafif artış göstermiştir. Öte yandan, $250 \mathrm{mg} \mathrm{l}^{-1}$ lik potasyum permanganat konsantrasyonunun üzerindeki dozlarda verim artışı (uygulanan doz artışına kıyasla) kayda değer gerçekleşmemiştir (Şekil 2). Böylece kimyasal çamur parçalamanın 1sıl işlemle birlikte uygulanması, uygulanan potasyum permanganat dozunun da ciddi oranda azalmasına neden olmuştur. Sonuç olarak, çamurun parçalanmasındaki kimyasal parametreleri dikkate alarak; $100{ }^{\circ} \mathrm{C}$ sıcaklıkta $250 \mathrm{mg}^{-1}$ 'lik potasyum permanganat uygulamasının optimum olduğu belirlenmiştir. Öte yandan belirlenen bu optimum şartlar, sadece 1 sıl işlemin uygulandığ 1 tüm sıcaklıklardaki ve sadece kimyasal oksidasyonun uygulandığ 1 tüm $\mathrm{KMnO}_{4}$ konsantrasyonlarında elde edilen çamur parçalama sonuçlarından daha iyi olmuştur. Sonuçta bu kombinasyonun çok daha az kimyasal uygulaması ile daha iyi çamur parçalama sonuçları vereceği belirlenmiştir.

Çamurun termokimyasal metotla parçalanabilmesinin bir diğer önemli göstergesi ise fiziksel bir parametre olan bulanıklık değerleridir. Şekil 4'te de gösterildiği gibi, kimyasal parametrelerdeki artışa benzer olarak, bulanıklık değerleri de sürekli artmıştır. Bu aynı zamanda çamurun parçalanması ile taneciklerin de küçültüldüğünün göstergesidir. Bunun bir diğer sonucu da, çamurun su verme özelliklerinin kötüleşmesi, yani kapiler emme süresi (KES) değerlerinin artmasıdır. Bu çalışmada öncelikli amaç çamurun çürütülmesini kolaylaştırmak olduğu için, KES değerlerindeki artış, dikkate alınmamıştır.

Tablo 3. Sinerjetik etkinin değerlendirilmesi.

\begin{tabular}{|c|c|c|c|c|c|c|}
\hline $\begin{array}{l}\text { Sicaklık } \\
{ }^{\circ} \mathrm{C}\end{array}$ & $\begin{array}{c}\text { Bulanıklık } \\
\text { NTU }\end{array}$ & $\begin{array}{c}\text { Karbonhidrat } \\
\mathrm{mg} \mathrm{l}^{-1}\end{array}$ & $\begin{array}{l}\text { Protein } \\
\mathrm{mg} \mathrm{l}^{-1}\end{array}$ & $\begin{array}{l}\text { çKOİ } \\
\text { mg l}^{-1}\end{array}$ & $\begin{array}{c}\text { PD }_{\text {коі }} \\
\%\end{array}$ & $\begin{array}{c}\text { KES } \\
\mathrm{S}\end{array}$ \\
\hline Isıl İşlem $\left(100{ }^{\circ} \mathrm{C}\right)^{\mathrm{a}}$ & 128.3 & 61 & 205 & 1215 & 11.9 & 41.7 \\
\hline $\begin{array}{l}\mathrm{KMnO}_{4} \text { ile } \\
\text { Oksidasyon (250 } \\
\left.\text { mg l-1 }^{\mathbf{b}}\right)^{\mathbf{b}}\end{array}$ & 180.1 & 92 & 256 & 1245 & 12.2 & 99.4 \\
\hline $\begin{array}{c}\text { Termokimyasal Ön } \\
\text { Arıtma }^{c}\end{array}$ & 250.7 & 160 & 390 & 2595 & 26.3 & 166.4 \\
\hline $\begin{array}{l}\text { Sinerjetik Etki } \\
(=\mathbf{c}-(\mathbf{a}+\mathbf{b}))\end{array}$ & $\mathrm{H}$ & $\mathrm{H}$ & $\mathrm{H}$ & 135 & 2.2 & $\mathrm{H}$ \\
\hline
\end{tabular}

H: Hesaplanmadı. Sinerjetik etki, KOİ parametresi esas alınarak incelenmiştir. 

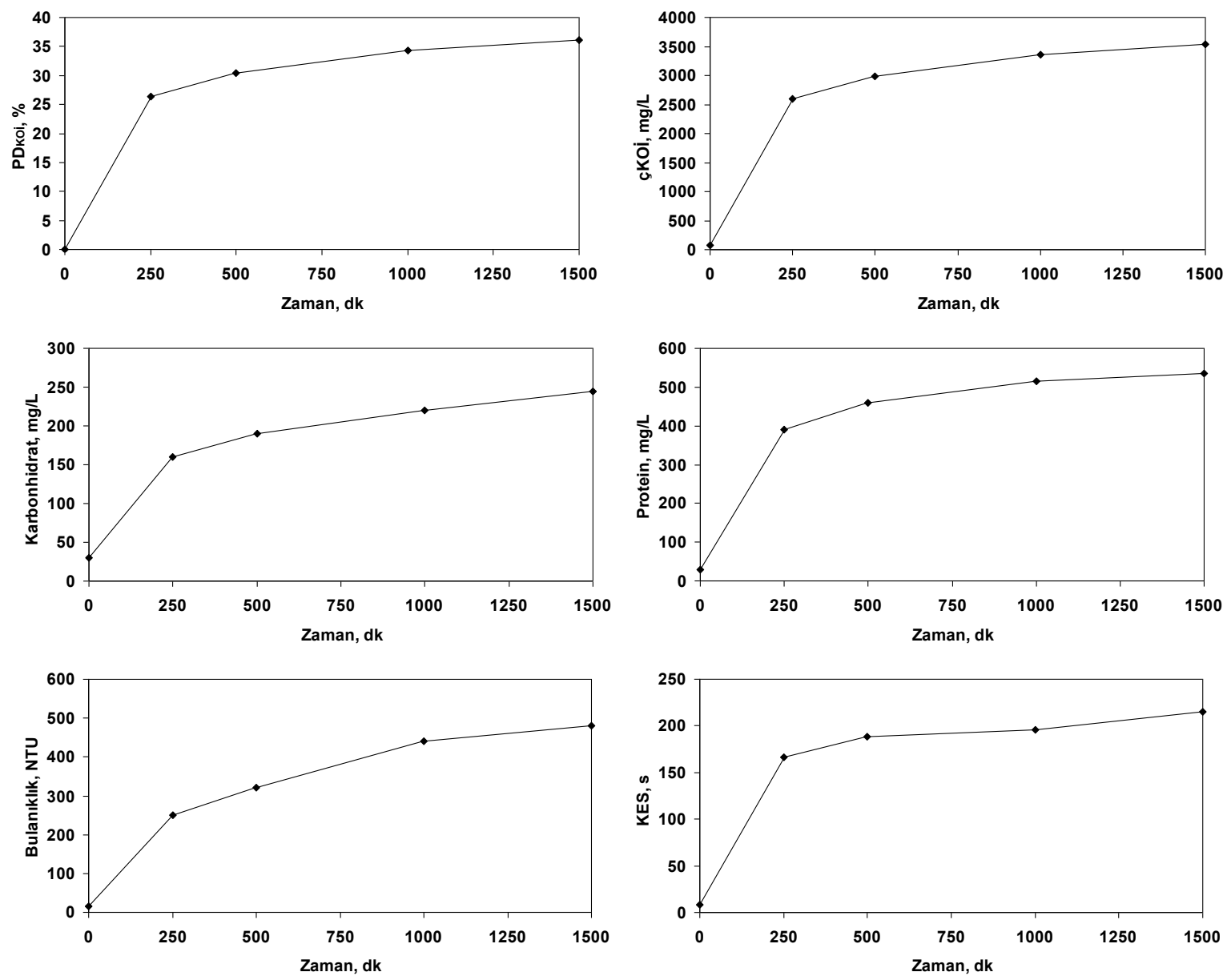

Şekil 2:

Termokimyasal metot ile çamur parçalama.

\subsection{Anaerobik Çürütmeye Etkisi}

Deneysel çalışmanın sonucunda, termal işlem için $100{ }^{\circ} \mathrm{C}$ sıcaklıkta, potasyum permanganat ile kimyasal çamur parçalama için $1000 \mathrm{mg} \mathrm{l}^{-1}$ 'lik konsantrasyon ve termokimyasal çamur parçalama için $250 \mathrm{mg} \mathrm{l}^{-1}$ ' lik potasyum permanganat dozu ile $100{ }^{\circ} \mathrm{C}$ sicaklık optimum şartlar olarak belirlenmiştir. Her üç metot ile çamur parçalamanın kesikli anaerobik reaktörlerde gaz üretimine etkisi, BMP testi ile belirlenmiştir. BMP testi ile çamur parçalama metotlarının anaerobik çürütme üzerine toksik bir etkisinin olmadığı görülmüştür. Şekil 3'te de ön arıtılmamış (ham) çamur ile farklı metotlarla ön arıtılmış çamurların kümülatif biyogaz ve metan gazı üretimleri gösterilmiştir. BMP testi gaz üretimi ihmal edilebilir seviyeye düşene kadar devam etmiş ve 60 gün sürmüştür.

60 günlük BMP deneyi süresince ham (ön arıtılmamış) atık çamurda toplam biyogaz üretimi 109,6 ml ve metan gazı üretimi $68,4 \mathrm{ml}$ iken; potasyum permanganat ile ön arıtmada toplam biyogaz üretimi $128,5 \mathrm{ml}$ ve metan üretimi $79 \mathrm{ml}$, 1s1l işlem ile ön arıtmada toplam biyogaz üretimi $120,1 \mathrm{ml}$ ve biyogaz üretimi $76 \mathrm{ml}$ ve termokimyasal ön arıtmada ise toplam biyogaz üretimi $151 \mathrm{ml}$ ve biyogaz üretimi $92,2 \mathrm{ml}$ olarak ölçülmüştür. Böylece, ham çamura kıyasla, termokimyasal metodun yaklaşık \% 38 oranında biyogaz ve \% 34 oranında da metan gazı üretimini arttırdığı belirlenmiştir. Çalışma kapsamında incelenen her üç metodunda çamurun anaerobik çürütülebilirliğini geliştirdiği belirlenmiştir. BMP testlerinin bu sonuçlarına 
göre, metotların çamurun çürütülebilirliğine etkileri şu şekilde sıralabilir: Termokimyasal ön arıtma $>$ potasyum permanganat ile kimyasal oksidasyon $>1$ sil işlem.

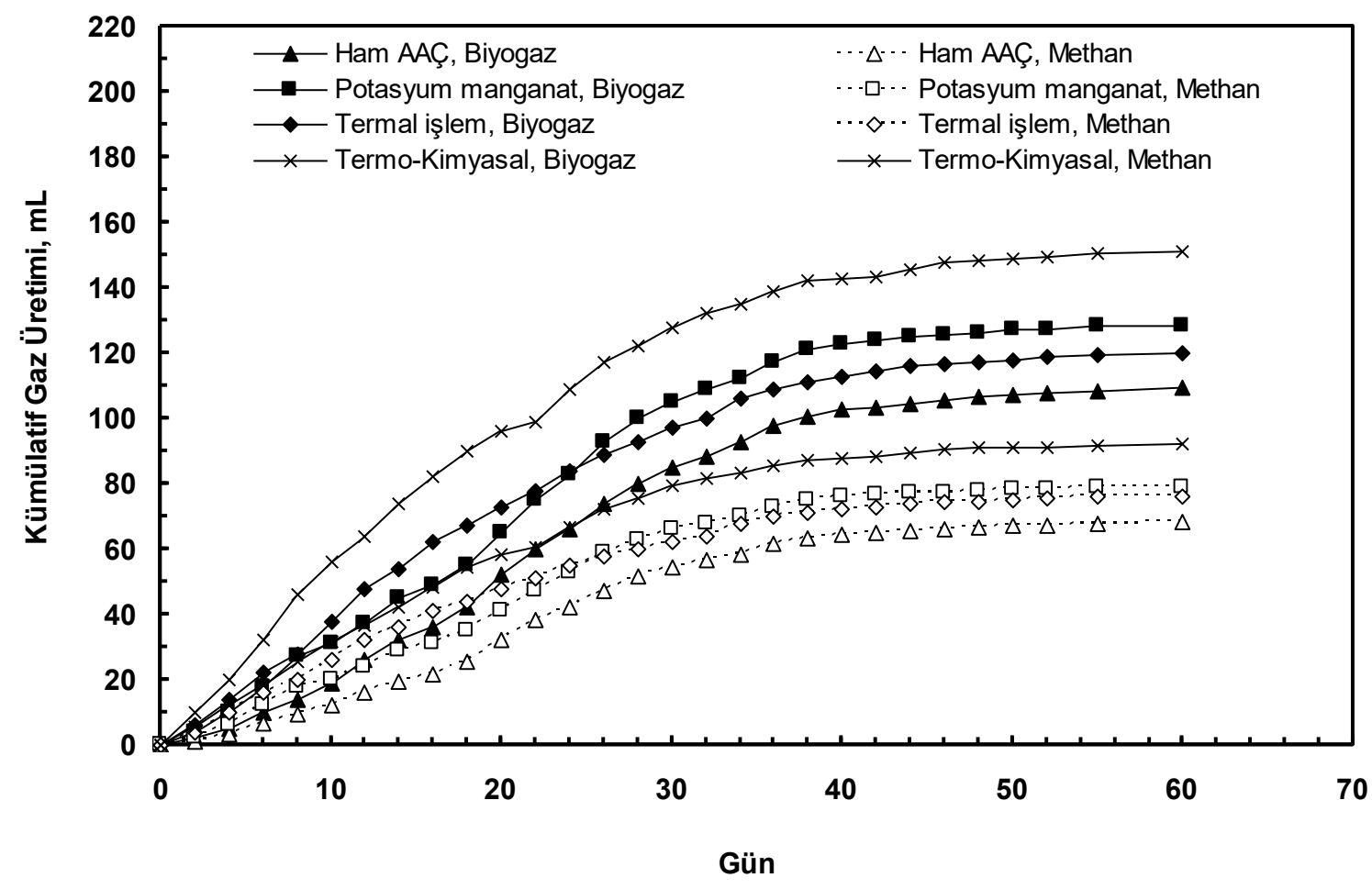

Şekil 3:

BMP testi sonuçlarına göre kümülatif biyogaz üretimi.

\section{DEĞERLENDİRME}

$\mathrm{Bu}$ çalışma kapsamında, 1 sıl işlem, potasyum permanganat oksidasyonu ve termokimyasal ön arıtmanın atık aktif çamurun fiziksel ve kimyasal özelliklerine etkisi ve çamurun anaerobik çürütülebilirliğine etkileri araştırılmıştır. Çalışma kapsamında elde edilen sonuçlar aşağıda özetlenmiştir;

- Is1l işlem için optimum sıcaklık $100{ }^{\circ} \mathrm{C}$ ve $\mathrm{KMnO}_{4}$ ile kimyasal oksidasyon için optimum konsantrasyon $1000 \mathrm{mg}$ 1-1 belirlenmiş iken; termokimyasal ön arıtma metodu için optimum şartlar, $250 \mathrm{mg} \mathrm{l}^{-1}$ lik potasyum permanganat konsantrasyonu ve $100{ }^{\circ} \mathrm{C}$ sıcaklık olarak belirlenmiştir.

- Ön arıtmanın, anaerobik süreçte her hangi bir toksik etkiye neden olmadığı aksine çamurun anaerobik çürütülebilirliğini geliştirdiği belirlenmiştir.

- Çalışma kapsamında incelenen ön işlem metotlarının çamur parçalama ve metan gazı üretiminde sağladıkları artış şu sırada gerçekleşmiştir: Termokimyasal ön arıtma > potasyum permanganat ile kimyasal oksidasyon $>1$ sıl işlem.

- Ön işlemin uygulanmadığı ham çamura kıyasla, termokimyasal ön arıtma ile kesikli reaktörlerdeki biyogaz üretimi \% 38 oranında ve metan $\left(\mathrm{CH}_{4}\right)$ üretimi de \% 34 oranında daha fazla gerçekleşmiştir.

Böylece termokimyasal ön arıtma süreci, atık aktif çamuru çürütme öncesinde parçalamak için etkin bir metot olduğu belirlenmiştir. Ancak ön arıtma prosesinin tüm etkilerinin 
belirlenebilmesi için sürekli beslemeli veya yarı kesikli beslemeli anaerobik çürütücülerde deneylerin yapılarak etkilerinin tam olarak belirlenmesi de gerekmektedir.

\section{TEŞEKKÜR}

$\mathrm{Bu}$ çalışmanın gerçekleştirilebilmesi için verdiği destekten ötürü, Nevşehir Hacı Bektaş Veli Üniversitesi Bilimsel Araştırma Projeleri (BAP) Birimine teşekkürlerimi sunarım (Proje Numaras1: NEUBAP16F26).

\section{KAYNAKLAR}

1. APHA/AWWA/WEF, in: Clesceri LS, Greenberg AE, Eaton AD. Standard Methods for The Examination of Water and Wastewater (21st ed.). American Public Health Association, American Water Works Association, and Water Environment Federation, Washington DC, 2005.

2. Carrère, H., Dumas, C., Battimelli, A., Batstone, D.J., Delgenès, J.P., Steyer, J.P., Ferrer, I. (2010) Pretreatment methods to improve sludge anaerobic degradability: A review, Journal of Hazardous Materials, 183, 1-15.

3. Demir, Ö. (2016) Potasyum Permanganatın çamur dezentegrasyonu üzerine etkileri ve ultrasonik ön arıtımla geliştirilmesi, Uludă̆ Üniversitesi Mühendislik Fakültesi Dergisi, 21, $2,189-200$.

4. Dubois, M., Gilles, K.A., Hamilton, J.K., Rebers, P.A., Smith, F. (1956) Colorimetric method for determination of sugars and related substances, Analytical Chemistry, 28, 350356.

5. Eskicioglu, C., Terzian, N., Kennedy, K.J., Droste, R.L., Hamoda, M. (2007) Athermal microwave effects for enhancing digestibility of waste activated sludge, Water Research, 41, 2457-2466.

6. Ferrer, I., Ponsá, S., Vázquez, F., Font, X. (2008) Increasing biogas production by thermal $\left(70{ }^{\circ} \mathrm{C}\right)$ sludge pre-treatment prior to thermophilic anaerobic digestion, Biochemical Engineering Journal, 42, 186-192.

7. Lowry, O.H., Rosbrough, N.J., Farr, A.L., Randall, R.J. (1951) Protein measurement with the Folin phenol reagent Journal of Biological Chemistry, 193, 265-275.

8. Sahinkaya, S., Sevimli, M.F., (2013) Sono-thermal pre-treatment of waste activated sludge before anaerobic digestion, Ultrasonics Sonochemistry, 20 (1) 587 - 594.

9. Vlyssides, A.G., Karlis, P.K. (2004) Thermal-alkaline solubilization of waste activated sludge as a pre-treatment stage for anaerobic digestion, Bioresource Technology, 91, 201206.

10.Wilson, C.A., Novak, J.T. (2009) Hydrolysis of macromolecular components of primary and secondary wastewater sludge by thermal hydrolytic pretreatment, Water Research, 43, 44894498.

11.Wu, C., Zhang, G., Zhang, P., Chang, C.C. (2014) Disintegration of excess activated sludge with potassium permanganate: Feasibility, mechanisms and parameter optimization, Chemical Engineering Journal, 240, 420-425

12.Zhang, X., Lei, H., Chen, K., Liu, Z., Wu, H., Liang, H. (2012). Effect of potassium ferrate $\left(\mathrm{K}_{2} \mathrm{FeO}_{4}\right)$ on sludge dewaterability under different $\mathrm{pH}$ conditions, Chemical Engineering Journal, 210, 467-474. 
